\title{
地場産業研究の意義と課題
}

\section{李哲 雨}

I はじめに

II 地場産業論の展開と地場産業の概念規 定

（1）地場産業論の展開

（2）地場産業の概念規定

III 地場産業の地位と構造変化
(2) 存立形態と発展段階

IV 地場産業と地域社会

(1) 地域社会との関わり

（2）地域開発に扔ける地場産業の意義

（3）地場産業の問題点と将来ヴィジョン $\mathrm{V}$ おわりに

（1）地場産業の地位とその変動

キーワード：地場産業, 産業地域社会, 地域主義, 社会的分業, 「地域論」的アプ ローチ

I はじめに

日本において，今日，いわゆる「地場産業」 として把握されている「中小企業の地域的集 積」は，その立地が地域的条件と深くかかわっ ていることから，経済現象と地域との関係を解 明しょうとする経済地理学にとって格好の研究 対象となってきた。特に高度経済成長期以降, これらの構造変化と低成長経済体制への移行の 結果，地域経済におけるその役割に注目が集ま った。その結果, 多くの研究が積み重ねられ, 「地場産業」という用語が定着するに至ってい る。もちろんこうした地場産業の研究は地理学 のみならず，他の諸分野，とりわけ中小企業論 でも盛んに行われてきた。

これまでの地場産業研究は, 共通の研究対象 に対して種々のアプローチの方法が試みられ,
研究テーマも様々であった。安定成長期に入り 十数年が経過した現在, 地場産業研究の各分野 及びテーマ毎の豊富な研究蓄積を整理し, 高度 経済成長期以降の地場産業の構造变化を客観的 に見直すことが次第に可能となりつつある。そ こで，本稿ではこれまでの業績をふりかえり， 筆者なりに地場産業研究の枠組みを再構成する とともに，研究課題を明らかにしようとするも のである。

地場産業という用語及び概念が登場したのは 日本に扔いてであり，地場産業研究も主に日本 をフィールドに行われてきた。しかし，地場産 業そのものは必ずしも日本独特の存在ではない, と指摘されており，近年，こうした視点にたっ て外国の事例研究も進められている。こうした 作業は，地場産業の一般性を検証するために非 常に重要であり, 海外地域での実証研究をさら

1）こうした研究の代表的な例としては, 辻本芳郎「郡内地方における機業の生産構造」, 新地理 $2-1,1953,12$-28頁, 伊藤喜栄「日本における中小織物業の地域的性格」，人文地理 $9-5,1957,17$ - 35 頁などが挙げられる。

2）地場産業研究文献目録は，下平尾勲『現代地場産業論』，新評論，1985，514一538頁，同『産業おこしとまちづくり』, 八朔社, 1989, 296一 - 317頁, 及び瀧澤菊太郎編『日本の中小企業研究』 3 巻, 有斐閣, 1985, 131一 151 頁に掲載されている。

3）板倉勝高『地場産業概念の発達』（板倉，北村『地場産業の地域』，大明堂，1980）10頁。

4）宮町良広「南アジア農村手織業の生産流通構造」，経済地理学年報，35-1，1989，1-22頁，及び板倉勝高『地場産 業の発達』，大明堂，1981，97-122頁。 
に積み重ねることが必要と考えられる。この場 合, 問題となるのは共通した研究枠組みと視点 であることは言うまでもない。従って，韓国に おける地場産業を研究課題としている筆者にと って, これらを検討する作業は, 実証研究を進 める前段階において取り組まねばならない必須 の要件となっている。

\section{II 地場産業論の展開と地場産業の概念規定}

（1 地場産業論の展開 日本経済は，1971年 のドルショックや1973年の第 1 次オイルショッ クとそれ以降の長期不況，そして円高（1977〜), 第 2 次オイルショックなどを契機に, 高度経済 成長期から低成長経済へと移行した。こうした 経済環境变化によって, 地場産業は多くの困難 に直面し，これを背景に地場産業の研究が盛ん になった。しかし，近年こうした困難はある程 度解決されつつある。これに対応するかのよう に，地場産業に関する研究も減少の傾向にある。 こうした傾向は，地場産業をとりまく環境の危 機が克服されつつあるという前述の現状を反映 したものであり，また，地場産業を産業把握の 新しい概念として取り上げて研究する視点が衰 え, 単なる地域振興の道具の一つとして位置づ けられる傾向が強まった結果である゙と考えられ る。しかし，地域振興策も地場産業論の枠内で 議論されていることを鑑みれば，地場産業に関 する諸見解を総合する試みはきわめて重要であ ろう。

前述したように，地場産業それ自体は古くか ら存在していたが, 従来は「在来工業」ないし は「伝統産業」と基本的に同等視され, 工業地 理学の範疇で研究されてきた。にもかかわらず,
1970年代になって，「地場産業」を学術用語と して用いる研究が現れた。そして地場産業は, 産業・地域政策の一つの手段として注目を浴び, それが地域産業発展，「町づくり」・「村おこし」 の鍵になりうるという見解が生まれるに至った。 そこで，地場産業に関する諸見解を検討する前 に，まず，その背景を検討してみる必要がある と考えられる。

地場産業研究に注目が集まった背景の第一に は，1960年からの高度経済成長期において日本 の産業構造が大きく変化する中で, 伝統的産業, あるいは在来工業といわれてきた産業集団が大 きく変容したことがある。長い歴史を持つ産地 においては，製品・原料・製造技術が急速かつ 全面的に変化し，中でも伝統的な生産方法を維 持している産地の多くは，停滞・縮小の方向を たどった。また逆に，新興産地のめざましい増 加・成長がみられるようになった。勇市の結果， 従来のような「伝統」・在来」という歴史的概 念に着目した定義ではそうした構造的変化を理 解することが困難となり，新たな概念規定が必 要となった。

第二の背景には，地場産業が地域と深いかか わり合いをもちながら育成，発達してきたこと から，地域の経済・社会の担い手として活躍し うるという見解が現れたことがある。1970年代 半ば以降低成長期に入ると，高度成長期にみら れた工業分散と財政による所得再分配などに依 存した地域経済の発展は困難となった。地域は, 高度成長期を通じて解決されなかった地域問題 に対応した地域振興と発展の方策に迫られ，従 来の中央依存の地域開発から脱却した内発的な 開発を求められるようになり，いわゆる「地方

5）上野和彦「地場産業概念に関する若干の覚書」，新地理34-2，1986，41頁。

6）「在来工業」と「伝統工業」の概念については，辻本芳郎『日本の在来工業』，大明堂，1978と磯部喜一『伝統産業論』， 有斐閣，1985を参照。

7）合田昭二ほか「伝統的漆器産業飛驒春慶の生産構造」, 経済地理学年報 $31-1 ， 1985,44$ 頁。

8）山崎 充『日本の地場産業』，ダイヤモンド社，1977と清成忠夫『地域の変革と中小企業』(上・下), 日本経済評論社, 1975参照。 
の時代」を迎えた。このような状況は, 地場産 業研究だけではなく, 政府の中小企業対策にも 大きな変化を招き，1979年には「産地中小企業 対策臨時措置法」が制定されるに至った。すな わち, 高度成長期における中小企業の構造変化 と安定期以降の課題を把握・解明するために地 場産業という概念が登場し, さらに, 地域主義 を思想的背景とした地域経済の発展の担い手と しての役割が期待されるようになり，いっそう 研究が進んできたと言える。

従って, 地場産業研究は, 大きく二つの立場 に区分できよう。すなわち一つは，地場産業を 産業把握のための新しい概念として捉える立場 であり, もう一つは, 地域社会, 地域経済の重 要な担い手としての地場産業の役割に着目して, 地域政策手段の一つとして捉える立場である。 前者の立場は, 中小企業研究における在来工 業 (固有工業) の研究に最も明瞭に表れている。 松井辰之助が「中小企業の時代的, 空間的な存 在形態の多様性と異雑性こそ, まさに本質的な 究明の必要理由」であると指摘したように，中 小企業の本質論を展開しょうとするならば，多 様な中小企業の具体的認識に基づかなければな らない。そうする際に，中小企業を先進資本主 義国から移植導入された近代工業と対比し, 近 代工業の移植導入以前にすでに発達を遂げてき
た固有の伝統的工業の存在形態や工業経営形態 の歴史的発展様相を究明しょうとするのが, 従 前の在来工業研究の視角であった。在来工業は 中小企業の一部とはいえ, 歴史的にみれば封建 社会に抒いて，商業資本の支配の下で手工業に 基づく家内工業の形態をとりつつ発達を遂げた。 その後, 資本主義社会に組み入れられ, 変容を 受けながらも，小規模企業が地域的に集積した 産地を形成し現在まで維持している場合が多い。 それゆえ在来工業研究では, 生産者が産地商業 資本により社会的に分業化され, 機能的に統合 された生産流通構造こそが産地存立の基礎構造 であるといったたように，在来工業の本質を明ら かにすることを研究の主眼としてきた。しかし 先述したように，在来工業あるいは伝統工業と 同等視することが可能であった中小企業の地域 的集積は，高度成長期を通じて大きく変化した。 こうした事態を受け，伝統工業・在来工業の変 化を中小企業問題として位置づけ, 地域産業構 造の変動を理解するための新たな概念として 「地場産業」を規定した研究が行われるように なったものである。こうした視点に立つ研究は, 地理学内部でも比較的早くから行われた。なか でも豊富な事例研究を基盤として地場産業の理 論的体系化を進めてきた板倉勝高は,「農業社 会から工業社会に移って，地域社会を特色づけ

9）こうした思想は「地域主義」と呼ばれている。地域主義を「地域に生きる生活者たちがその自然・歴史・風土を背景に, その地域社会または地域の共同体に対して一体感をもち, 経済的自律性を踏まえて, 自らの政治的・行政的自律性と文化 的独自性を追求すること」であると玉野井芳郎は定義している。そして地域主義に関する文献としては, 杉岡碩夫編『中 小企業と地域主義』, 日本評論社, 1973, 同『地域主義のすすめ』, 東洋経済新報社, 1976, 清成忠男『地域の変革と中小 企業』(上・下), 日本経済評論社, 1975, 同『地域主義の時代』, 東洋経済新報社, 1978, 三輪公忠『地方主義の研究』, 南空社, 1975, 玉野井芳郎『地域分権の思想」, 東洋経済新報社, 1977, 玉野井芳郎・清成忠夫・中村尚司・益田四郎編 『地域主義一新しい思潮への理論と実戦の試み一』, 学陽書房, 1978, 今井賢一・中村秀一郎編『地域からの産業論』, 筑 摩書房, 1980などが挙げられる。

10） 中小企業分野の研究は, 分類視点によって多様に区分できると考えられる。板倉勝高・井出策夫・竹内淳彦『大都市零 細工業の構造』では, 「社会政策論的な研究」,「在来工業（固有工業）の研究」「下請制の研究」,「労働問題としての研 究」に分類されている。

11）松井辰之助「中小工業の本質とその存在形態」（藤田敬三編『中小企業の本質』，有斐閣，1954）232頁。

12）合田昭二「知多綿織物業の地域的存立基盤」, 地理学評論 $44-7,1971,498$-499頁。

13）個別的な研究だけではなく1973年日本地理学会の秋季学術大会で, 地場産業に関するシンポジウムも行われた。この結 果をまとめたのが板倉勝高・北村嘉行編『地場産業の地域』，大明堂，1980である。 
る『産業地域社会』として地場産業の研究は, 地域社会の位置づけを明らかにする役割を担っ ている。これは，地理学界が社会から託された 使命の一つであって，さればこそ地場産業の研 究は，まず地理学界において手がけられたので あった」と展望した。もっとも地理学の側から の研究は, 詳細な地域的分析を行ってはいるも のの，当該地域における諸要素の関連分析が中 心であり，国全体の工業あるいは中小企業全体 との関連や全国的位置づけに力点を置くことは なかった。

これに対し，地場産業を地域経済の主要な担 い手として把握しようとする研究は，いわゆる <地域主義論〉者を中心に行われ，現状の解明 を最終目的とするのではなく, 将来ヴィジョン を提示することに力点を置いている。経済の低 成長期以後，地方への工業分散に大きな期待を 寄せることはできず，また財政を通じた地方へ の所得移転効果にも高度成長期のようには期待 をかけることができなくなった。地域振興の必 要な地方においては，内発的かつ自立的な産業 化の道が追求されるようになった。言い換えれ ば，地域がリーダーシップをにぎり，生活福祉 と直結した形の産業政策が求められるようにな り，地域独自の中小企業を確立することによっ て地域経済を自立させる必要性が強調されるよ うになった。その際に地場産業は，地域や地域 経済と強い結びつきを持つ中小企業の 1 つの夕 イプであることや，地域経済の発展に果たして いる役割の大きさの点から注目を集めてきた。 とりわけ豊富な事例を用い，統合的分析を行っ
ている山崎充の『日本の地場産業』は，地場産 業の振興と今後のあり方に大きな示唆を与えた。 彼は，まず一義・一元的な定義は困難だとしな がらも地場産業の定義を行い, 多様な地場産業 を類型化してその特性を明らかにした。さらに 地場産業の多様な実態をふまえ，量産化・機械 化を試み，国際化を進めた産地は高度経済成長 期には発展したが，安定成長期になるとむしろ 他産地より一層大きな打撃を受けたことを指摘 した。そして今後発展する可能性を秘めた産地 は，技能集約型で企画力，開発力を持つ産地， 異技術を取り入れることができ，多品種少量生 産ができる産地，短期的な変化に応じて質的変 換を行える産地であると示唆し，地場産業を経 済的基盤とする地方都市の建設を主張した。し かし山崎の提唱した「地場産業都市」は，地場 産業を地方都市形成の基盤とするという点では 明快であるが，情報産業などサービス産業との 関係や，先端技術との関連が必ずしも明確では ないという批判もある。一方, 清成忠男は地域 主義を主張し，中小企業のあり方を論じる中で， 「地場産業の健全な発展によって中小企業が安 定し, 地域社会が安定するのである」と指摘し, 「地方の時代」を実現するための自立的な産業 化政策において地場産業の持つ意義の重要性を 強調している。

しかしながら，地域政策の手段として地場産 業を捉えようとする研究は，地場産業が中小企 業の「地域的集団」に根ざしているにもかかわ らず，その焦点を「加工部門」に限定し，「産 業」としての地場産業の特性をとらえることに

14）『産業地域社会』については, 1)井出栄夫「大都市零細産業集団の内部構造」, 地理学評論46一10，1973，668一674頁。 (2)宮川泰夫「地域的産業集団と産業地域社会」，経済地理学年報 $20-2 ， 1974 ， 3-17$ 頁。(3)竹内淳彦『技術集団と産業 地域社会』，大明堂，1983，162-203頁。(4)板倉勝高編『地場産業の発達』，大明堂，1981，17一25頁を参照。

15）板倉勝高 - 北村嘉行編『地場産業の地域』, 大明堂，1980，11頁。

16）杉岡碩夫『中小企業と地域主義』, 日本評論社, 1973, 1 頁。

17）瀧澤菊太郎編『日本の中小企業研究』第 1 巻，有斐閣，1985，276頁。

18）山崎 充『日本の地場産業』, ダイヤモンド社, 1977。

19）山崎 充『地場産業都市構想』，日本経済評論社，1981。

20）前掲17）278頁。

21）清成忠男『地域の変革と中小企業』(上), 日本経済評論社，1975，148頁。 
拘泥し，立地ないし地域という点を素通りした 議論しか行われなかった。従って，それに対す る政策は「加工部門」を中心とする「産業」振 興を目的とするものであった。政策対象として 地場産業を考えようとする場合には，単なる産 業振興よりも地域振興の視点からその振興を図 る必要があり，「加工部門」のみならず，「流通 部門」も含まれなければならないと思われる。 なぜなら，地場産業の成長につれて市場や販路 の問題はその重要性を増すため,「流通部門」 が地場産業振興および地域振興にとって，極め て大きな役割を担うからである。さらに地場産 業の概念から考えても，「流通部門」を除外す る理論的根拠は見当たらない。

以上，地場産業をめぐる議論において，地場 産業は，「地域」とのつながりがきわめて強く， その「地場性」が地場産業研究にとって重要で あることが一貫して指摘されている。しかしな がら，「その産業がある地域に立地ないし集中 している意味，あるいはその地域経済とのかか わりあいが，深く研究されることは殆どなかっ たといっても過言ではない」と, 青野壽彦が鋭 く指摘しているように, 地場産業論には地域社 会のあり方に視点を定めた地域論的観点にそし かったことは事実である。

（ 2 地場産業の概念規定 上述したように, 1970年代以降,「地場産業」が新たな産業把握 の概念として定着し, 数多くの研究が行われて きた。しかし，地場産業という用語は，明確な 基準がないままに，きわめて便宜的に用いられ る場合が多く，その性格も十分には整理されて いないため, 確固たる定義が存在しないのが現 状である。そこで, 地場産業の概念と性格を考 えるために，まず「地場産業」という用語の意
味自体の検討から始めてみたい。

「地場」という用語は, 証券取引市場におい て使用されていた「地場資本」から流用したも のである。その場合の「地場資本」というのは, 大手，仕手の資本に対して，取引所所在の地域 で蓄積された小資本集団を意味していた。つま りこれは，取引所のある地元に密着し，中央資 本やそれにつながる大手筋とは無関係な小口・ 零細資本を意味しており，資本の所在を含意す る言葉でもあった。こうした意味をもつ「地 場」という言葉が工業集団に転用された場合, その工業集団は，国家資本を背景にした中央資 本によるものではなく，地元の小資本による工 業集団を指すであろう。しかし，この場合に 「地場工業」ではなく「地場産業」という表現 を用いる理由に関して，板倉勝高は，関連する 諸産業を含めた産業集団を示すためであると主 張した。すなわち, 零細工業集団は, 工業が単 独で存在することはありえず，その生産物を広 範囲の市場に流通させる媒介者として商人の存 在が不可欠であり，これらに交通・運輸・金融 などを加えた産業集団を指す用語としては「地 場工業」よりも「地場産業」がより適切と考え られる。

ところで，こうした意味内容をもつ地場産業 は，生産品，あるいは規模によって定義された ものではないため,「産業的・企業的・経営的 特性が異なる多数の産業, それを構成する膨大 な数にのぼる企業の集合体であるが故に，極め て多様・異質・多元的存在であるため，その定 義を一元的，かつ明確に下すことは容易なこと ではない」と指摘されている。それゆえ，一口 に地場産業と言っても，その内実は非常に複雑 で，各産地は，歴史，立地，生産流通，技術あ

22）青野壽彦「地場産業と地域振興」，地域開発 $190 ， 1980 ， 3$ 頁。

23）湖尻賢一「地場産業研究の方法について」, 商経論叢 $20-3$, 九州産業大学, 1980, 98頁。

24）前掲15） 8 - 9 頁。

25）前掲15） 9 頁。

26）前掲18） 4 頁。 
るいは社会的分業体制の面からも，当面する問 題についても，それぞれ違っている。その結果， 確固とした共通の理解はそしく，様々な議論が なされている。

そこで，次に地場産業の概念規定をめぐる議 論を詳細に検討してみようう。清成忠男は，日本 の中小企業のタイプを，市場，立地及び社会的 分業の基準から，(1)地域産業型，(2)地場産業型， (3)大企業の生産関連型，(4)その他など 4 つに区 分し，地場産業を「地域の特産品である消費財 を全国市場ないしは外国市場に供給する産業」 と定義した。そして，地場産業の特徵を(1)社会 的分業が進展し, 外部経済が蓄積され, 全体と しては有機的な構成体である産地が形成されて いること，(2)一定の歴史的展開の結果，様々な 経営資源が蓄積されていること，(3)労働集約的 で技能に依存する産業が多いこと，(4)生産流通 の担い手である企業のほとんどが中小企業であ ること，(5)システム・オーガナイガーとしての 役割を果たす企業が存在し，産地を組織してい ること，という5つの点にあると指摘した。山 崎充は，地場産業が中小企業の内の一つの固有 のタイプであることを大前提とし，清成忠男の 分類に基づく次の $5 つ$ 特性を備えたものを地 場産業として定義した。すなわち，(1)特定の地 域に起こった時期が古く，伝統をもつ産地であ ること，(2)特定の地域に同一業種の中小零細企 業が地域的企業集団を形成して集中立地してい ること, (3)生産・販売構造がいわゆる社会的分
業体制を特徵としていること，(4)他の地域では あまり産出しないその地域独自の「特産品」を 生産していること，(5)地域産業とは違って市場 を広く全国や海外に求めて製品を販売している こと, である。一方, 板倉勝高は, 大都市の零 細工業集団を，(1)近在必要工業，(2)地場産業， (3)機械金属工業，の3つに分類した。そして 地場産業は，日用消費財の狭域生産としての近 在必要工業と区別されるものであることと，中 央資本によらない中小零細規模の地域集団であ ることをその要件とする，「零細企業の地域集 団による広域商品の生産流通体系」であるとし た。こうした見解に加えて，竹内淳彦は，地場 産業の性格を，(1)同一製品，あるいは同一工程 の作業に関係する小規模企業が一定地域内に集 中立地している地域的産業集団であり，(2)集団 内には製品の生産と流通を通じた社会的分業が 存在し，(3)これらの工場等は，中央資本によっ てではなく，地元資本によって運営され，(4)そ の市場が地元だけでなく，全国とか世界とかい った広域市場に依存して成り立っている，等に 整理した。また，中小企業庁の「中小企業白 書」では, 「地元の資本により, 一定の地域に 集積しつつ, 地域の経営資本 (原材料, 技術, 労 働力等）を活用して製品を生産し，その販売先 を地域のみならず地域外にも求める産業」とい う概念規定が，地場産業に与えられている。

以上の見解を総合すると, 地場産業は中小企 業における典型的な存立タイプである点と, 地

27）代表的な研究者の文献を以下に挙げる。

(1)清成忠男の『現代中小企業の新展開』, 日本経済新聞社, 1972, 前掲21）と「地場産業の現代的意義」, 地域開発190, 1980，43-50頁。

(2)山崎充の前掲18) 及び19）と『地域経済の活性化の道』，有斐閣選書，1986。

(3)板倉勝高の前掲 4 ) と前掲15)。

(4)中小企業庁『中小企業白書』1980。

28）清成忠男『現代中小企業の新展開』, 日本経済新聞社，1972，52-53頁。

29）清成忠男『地域主義の時代』，東洋経済新報社，1978，83頁。

30）清成忠男「地域開発と地場産業」，地域開発 $116 ， 1974 ， 1-2$ 頁。

31）前掲18） $3-9$ 頁。

32）板倉勝高 ·井出策夫 ·竹内淳彦「大都市零細工業の構造」, 新評論, 1973，20-21頁。

33）前揭 4) 序。

34）竹内淳彦「地場産業と都市・都市工業」（前掲15)）23一24頁。

35）前掲27）の(4)246-247頁。 
域との関連性，いわゆる「地場性」が欠かせな い要件である点では共通している。しかし，若 干の見解の差も認められるため，相違点を整理 し具体的に検討してみよう。

まず第 1 に，金融（資本）のあり方について， 清成忠男と山崎充は積極的には注目していない。 これは零細企業集団であるため強調する必要が ないと考えたためとも思われる。けれども，中 央の大資本が特定の地域に進出し,「産地」に 対する活動をしても，地場産業とは言えないと 考えられるため, 資本の地場性を地場産業の特 性として取り上げる必要があると思われる。第 2 に, 清成忠男が社会的分業体系を地場産業の 特性として取り上げたことに対して, 板倉勝高 は「資本主義社会というものが社会的分業の上 に成り立っているので，指摘するものではない とも考えられる」と指摘した。しかし，ここで いう社会的分業は, 産地内部での社会的分業, 特に生産と流通，さらには同一工程上の社会的 分業を意味しており, 地場産業の生産流通体系 においてもっとも重要な特徴であると同時に, 各種の経営資源を蓄積させ, 産地の存続を左右 する大きなファクターとなっている。さらにこ れは近年の地場産業研究の一つの大きな成果で あるとも指摘されており 地場産業の重要な特 性と言ってもよいと思われる。第 3 に, 山崎充 が指摘した産地形成時期の古さと伝統性の問題 は実態にそぐわないと思われる。確かに，伝統 工業から発達したものも数多く存在するが, 発 生は古くとも盛んになったのは比較的新しい場 合も少なくないし, さらに戦後の新興産地も存
在する。山崎充自身も事例分析においては, 「現代型」という用語で新興産地をも扱ってい る。第 4 に, 製品について, 山崎充が「特産 品」として扱っているのに対して, 清成忠男は 「消費財」として扱っている。しかし, 山崎充 はその後,「特産品的な消費財」と指摘してい るのので両者の間には大きな相違はない。そして， 板倉勝高は，消費財以外に生産財を生産する例 を挙げながらも，日用消費財が多いことから 「大体に损いて日用消費財」という程度の属性 を指摘した。

以上地場産業の概念と性格を検討してみたよ うに，地場産業は，最終製品による業種区分や， 規模による区分とは範疇を異にする，いわば産 地の属性を基にした概念であるといえる。ここ ではひとまず，地場産業とは「地元資本をべー スとする中小・零細企業の地域集団による社会 的分業に基づいた広域商品の生産流通体系」と 定義しておく。

\section{III 地場産業の地位と構造変化}

（1）地場産業の地位とその変動 地場産業は, 中小企業の中でも, 当該地域の地域経済・地域 社会のあり方を極めて強く規定しており, 独特 の存在として意識されることが多かった。その ため, 個別産地を対象とした産地の変化と地域 経済との関連に着目しながら研究が進められて きた。しかし, 地場産業が, より広い諸産業分 野の一員として，国民経済の中に存在している ことは言うまでもない。ところが，地場産業を 全国的なレベルで把握し，それを国民経済の全

36）前掲15）2 頁。

37）前掲30） 2 頁。

38）前掲22） 2 頁。

39）「現代型」産地として白鳥の手袋産地を取り上げて分析を行った（前掲18）67一74頁)。

40）山崎 充『地域経済の活性化の道』, 有斐閣選書, 1986, 61頁参照。

41）前掲15） 3 頁。 
体構造のなかに位置づけようとする研究事例は 極めて少ない。その理由は, 全国的なレベルで の地場産業の実態を的確にとらえることのでき る統計資料は皆無に近いという事実にある。従 って，日本における全国レベルでの研究はすべ て, 数少ない統計資料である全国商工会連合会 の『小規模事業対策調查報告書』（1973）と中 小企業庁の『昭和49年度中小企業産地概況結果 表』（1975）及び『図説我が国の産地』（1981） に依拠せざるを得ない。さ年) さらに，こうした資料 も，地場産業とほぼ同義とはいえ，中小企業庁 による「産地産望」うという定義に基づいた調査 の結果である。

具体的な統計資料に基づく地場産業の全国的 なレベルでの検討は，全国商工会連合会の調査 結果を基本として，自らの地場産業の概念規定 にしたがって修正した321の地場産業を対象に, 業種別・地域別分布と，地場産業の地位とその 変動を検討した，清成忠男が最初であろゔ。彼 は，地域別には関東以西に $90 \% か ゙$ 集まり，関東 以西から近畿以東の産地が過半数を占めること, 業種別には繊維が圧倒的であることを指摘した。 さらに，製造業全体における地場産業の地位と その変動について, 地場産業は, かつて, 日本 経済のうえできわめて重要な地位を占めていた が，1960年代後半以後の急速な重化学工業化の 過程でその地位は次第に低下し，1972年以後は 絶対的にも縮小傾向にあることをも指摘した。

山崎充は, 地場産業の立地していない都道府
県はないことから，地場産業が地域経済と深い かかわり合いをもつ産業であり，近年地域経済 に占めるウェートが低下してきたとはいえ，地 場産業を抜きにしては「地域」の経済的・産業 的・社会的問題を語れないと主張した。。そして, その地位と変動に関しては高度成長期以後の構 造変化を中心に問題点を明らかにして，将来の 展望を提示した。

こうした高度経済成長期以後の地場産業を取 り巻く環境変化とそれに伴う地場産業の構造変 化は，全国的なレベルよりもむしろ，個別産地 の研究において多くの研究者の注目を浴び，地 場産業研究の主流を占めるようになった。個別 産地に㧍ける地場産業の構造変化に対しては, いくつかの見方が示された。

まず，需要構造の変化から説明するものがあ る。地場産業の多くは消費財生産を担当するた めに，主たる市場を構成するものは個人消費で ある。それゆえ，国民の所得・生活水準が地場 産業の発展と直接に深いかかわりをもつことに 着目し，国内消費構造から地場産業の構造変化 を論じるべきであるとする立場がある。第一に 挙げられる国内消費構造変化は，明治維新以来 の近代化の底流にある「洋風化」の動きであり， それは特に戦後，急速に進展した。生活様式の 洋風化によって衰退を余儀なくされた地場産業 もあるが，反対にうまく適応して成長した地場 産業も存在する。第二の変化には，高度成長期 以後の生産力の飛躍的な拡大と所得水準の向上

42）こうした研究としては

(1)清成忠男「地域開発と地場産業」, 地域開発116, 1974, 1-8 頁。

(2)山崎充の前掲18）9-23頁と『地域経済活性化の道』，有斐閣新書，1986，60一77頁。

(3)北村嘉行「日本の地場産業(1)-(3)」, 地域 1 号-3 号, 1979・1980。

(4)合田昭二「地場産業と国民経済」（板倉・北村『地場産業の地域』, 大明堂, 1980）33-45頁等が挙げられる程度である。

43）前掲18）9 頁。

44）全国商工会連合会の調查は年間生産額 3 億円以上を調査した結果，368産地にのぼっているが，中小企業庁の調查は 5 億円以上を対象にした結果, 330産地が調査された。

45） 1970年版中小企業白書では「中小企業の集積形態の一つとして，同一の立地条件の下で，同一業種に属する製品を生産 し，市場を広く全国や海外に求めて，製品を製造，販売しているいわゆる産地と呼ばれる企業集団」を産地産業と規定し た（中小企業庁『昭和45年版中小企業白書』1970，156頁)。

46）前揭30） $3-5$ 頁。

47）前掲18）20頁。

48）合田昭二「地場産業と国民経済」（前掲15））43頁。 
による，消費水準の一貫した上昇がある。その 結果, 消費財需要の拡大 ·大量消費の時代が到 来し, 供給構造の変化も加わって, 地場産業の 量産化が進むこととなった。国内需要の増加は, 輸出型産地の基盤でもあった。というのは, 輸 出型産地といえども, その多くは内需に依存し ていたからである。こうした高度成長期におけ る国内市場の好調は, 地場産業の構造を変化さ せながらもその存立基盤を支えてきたと言える。 第三の変化は, 低成長期に入り, 高度経済成長 過程で生じた地場産業の存立基盤が動摇し，か つてない深刻な事態を迎えたことである。他方， 高度成長期後半から国内需要に変化が生じはじ めた。いわゆる，「生活の質」の追求による本 物指向, 高級化・多様化・個性化を指向する需 要変化である。その結果, 市場の多層化が進ん だ。こうた需要変化への適応過程において, 既存地場産業の再組織化や新しい地場産業の創 出といった試みが各地で行われ始めている。

次に, 供給構造に着目して地場産業の構造変 化を論じようとする見方があり，そうした研究 では, 特に労働力と原材料の供給に関心が集ま った。地場産業産地の形成とは，「地場資本に よって, 地域の資源や労働力が組織化され, 製 品を生産するための地域的体系が成立するこ と」であるとの定義もあるが, 現実の地場産業 にあっては，原材料の大部分は産地外から調達 され，産地内原材料の独占による利益獲得は少 なく，労働力も必ずしも地元だけに依存してい るとは言えないのが現状である。それでも，依 然として労働力と原材料は, 産地構成または産 地の存立における供給面での重要な要素である と考えられる。供給構造に著しい変化が生じた のは高度成長期以降であり, 以下, 労働力と原 材料のそれぞれについてみてみよう。
(1)労働力: 経済の高度成長による雇用機会の 拡大は，一般に労働力不足をもたらした。1960 年代後半からは，製造業の小・零細企業におい ても, 雇用の拡大が顕著である。地場産業は, 第 2 次大戦以前の労働力過剩・低賃金の時代に, 農業と並んで過剩人口のプールとなった分野で あるが，高度成長期に入ってからは，農業とは 対照的に，むしろ雇用を拡大させていったので ある。しかし，地場産業労働力の主力は，家族 従事者および産地内の中高年齢層であった。従 って, 従事者の高齢化とともに労㗢力の不足と 後継者難が進行した。それでも賃金水準は上昇 し，賃金による生産コストの上昇という事態を 余儀なくされるに至った。こうした事態への対 応として, 社会的分業が拡大していく一方, 多 くの産地は資本集約的生産方法を指向するよう になった結果，産地としての独自性を喪失する 場合もしばしばみられたのである。

(2)原材料 : 地場産業には資源立地型が総じて 多い。その中でも原材料を地元の農家の副業に 依存しているものも少なくなかった。かつては， これらの原材料が，農家にとって重要な現金収 入源だった。しかし，高度成長期においてこの ような状況は一変した。すなわち, 農家労働力 の農外就業の急激な増加により，労働集約的な 原材料の生産は衰退の一途をたどった。さらに 石油化学産業における技術革新による，いわゆ る「材料革命」の結果, 新しい非農産原材料が 出現し, 農家生産に依存した原材料の不足を補 い，それに置き替わる傾向がいっそう進んだの である。

最後に, 国際関係から地場産業の構造変化を 捉えようとする見方がある。高度成長期におけ る地場産業は，存立条件の大きな变化を伴いな がらも，全体としては相対的に安定していたが,

49） 1971年当時, 輸出産地とされる輸出比率 $10 \%$ 以上の産地の平均輸出率は $41.8 \%$ を占めていた。

50）清成忠男「地場産業の現代的意義」，地域開発190，1980，47頁。

51）上野和彦・西村龍平「地場産業地域の形成に関する一考察」，経済地理学年報36-2，1990，47頁。

52）前掲48）37頁。 
一部には著しい成長もみられた。これは，もち ろん, 上記の国内需要拡大や, 労働力の不足, 「材料革命」とも関連を持つだろう。しかし， 生産手段の近代化を通じた資本集約的な量産化 が進展し，輸出特化型産地が一部に形成された のは，円安経済と輸出振興政策に支えられた， 輸出の増加の役割が大きいと指摘されている。 しかし1970年代に入り，こうした状況に変化が 生じた。すなわち, 前述した一連の国際環境の 変化（特に通貨調整）によって，国際競争力が 弱まり，発展途上国の追い上げが次第に強まる につれ，輸出が伸びなやみ，一挙に矛盾を露呈 するようになった産地が多数みられた。さらに, 輸出型産地ではなくても, 発展途上国からの輸 入の増大のために，国内市場での競合問題が生 じる等の問題に直面するようになった。このよ うな国際環境の変化への地場産業の対応は様々 で，海外投資が行われることもあった。

以上, 地場産業の構造变化に対する諸見解を 整理したが，これらの諸見解は構造变化に関し て有益な見方を提示したとは言え，仮説にとど まっていると言えよう。なぜなら，地場産業の 構造変化に関するこうした環境変化は必ずしも 地場産業に限られるものではないにもかかわら ず，環境変化が及ぼした影響を地場産業とその 他の産業との間で実証的に比較・検討した研究 は，これまでのところ皆無に等しいからである。 さらに，3つの側面間の相互関連についても明 らかとはなっていない。また分析のほとんどは 高度成長期以後に限られている。したがって, 高度成長期以前の時期までふまえた地場産業の 地位とその変動の検討が必要であると考えられ る。上野和彦による「織物産地の発展・衰退を 日本資本主義の発展段階との関係において論じ た研究は少なかった。そこで社会・経済史的視
点を導入することが必要」と要」と指摘は, 織物だ けでなく地場産業全般の研究にとってもきわめ て重要なこもであろう。

( 2 ) 存立形態と発展段階 既に述べたように, 日本における地場産業は広く全国に分布し, 地 域的条件と深くかかわった独自の経営資源の蓄 積を基盤として発達したきたため，地場産業の 発展過程と存立形態は極めて多様である。それ ゆえ，地場産業を全体として捉え，存立形態を 検討しょうとする際には，何らかの基準で類型 化して分析する方法が有効であろう。

地場産業の類型化は，現在の存立形態だけで はなく, 発展系列的な側面からも捉えることが 可能である。しかし，発展段階に焦点を当てた 類型化に関する研究は極めて少ない。その背景 には，地場産業自体を純学術的に研究しょうと するよりは，地方化時代において地場産業を地 域経済振興の担い手として捉え, 現存する地場 産業の特性や問題点を明らかにすることでその 振興策を探ろうとする強い問題意識が存在する ためであると考えられる。

ともあれ，まず地場産業の存立形態の類型化 に関する研究を検討してみることにする。こう した類型化においては，その基準が重要であろ う。そこで，地場産業の各類型を分類基準別に 整理したのが第 1 表である。

ここでは, 立地, 歴史, そして産業組織を主 要な分類基準として取り上げる。

$\mathrm{A}$ ：立地による区分

立地による区分は，地場産業の存立形態が立 地場所によって違ってくるという点から，最も 重要視されてきた。

山崎充は都市型と地方型に立地を区分し, 都 市型を「大都市に立地したもので，大都市しか 持っていない知識・情報を充分に活用してデザ

53）前掲30） 7 頁。

54）前掲48）35頁。

55）上野和彦『地場産業の展望』, 大明堂, 1987，5頁。

56）前掲30）2 頁。 
第 1 表 地 場 産 業の類 型

\begin{tabular}{|c|c|c|c|c|c|}
\hline 基 準 & 立 地 & 歴史 & 市場 & 産業組織 & その他 \\
\hline 山崎 充 & $\begin{array}{l}\text { 都市型 } \\
\text { 地方型 }\end{array}$ & $\begin{array}{l}\text { 伝統型 } \\
\text { 現代型 }\end{array}$ & $\begin{array}{l}\text { 輸出型 } \\
\text { 内需型 }\end{array}$ & $\begin{array}{l}\text { 産地完結型 } \\
\text { 非産地完結型 }\end{array}$ & $\begin{array}{l}\text { 社会的分業型 } \\
\text { 工場一貫生産型 }\end{array}$ \\
\hline 清成忠男 & $\begin{array}{l}\text { 大都市型 } \\
\text { 地方都市 · 農村型 }\end{array}$ & $\begin{array}{l}\text { 伝統的在来型 } \\
\text { 在来化した外来型 } \\
\text { 変化した在来型 } \\
\text { 新興型 }\end{array}$ & $\begin{array}{l}\text { 内需指向型 } \\
\text { 輸出指向型 }\end{array}$ & $\begin{array}{l}\text { 独立型 } \\
\text { 従属型 }\end{array}$ & $\begin{array}{l}\text { 手工業型 } \\
\text { 家内工業型 } \\
\text { マニュファクチャー型 } \\
\text { 工場型 }\end{array}$ \\
\hline 杉岡碩夫 & $\begin{array}{l}\text { 都市型 } \\
\text { 地方型 }\end{array}$ & & & $\begin{array}{l}\text { 垂直的構造型 } \\
\text { 水平的構造型 }\end{array}$ & \\
\hline 板倉勝高 & $\begin{array}{l}\text { 大都市型 } \\
\text { 地方都市型 } \\
\text { 農村型 }\end{array}$ & & & & $\begin{array}{l}\text { 小商品型 } \\
\text { 製造卸型 } \\
\text { 小工場型 }\end{array}$ \\
\hline 青野壽彦 & & & & $\begin{array}{l}\text { 垂直的構造型 } \\
\text { 水平的構造型 }\end{array}$ & $\begin{array}{l}\text { 単一業種型 } \\
\text { 複数業種型 }\end{array}$ \\
\hline 北村嘉行 & $\begin{array}{l}\text { 大都市型 } \\
\text { 大都市周辺型 } \\
\text { 地方都市型 } \\
\text { 農村型 }\end{array}$ & & & & \\
\hline 合田昭二 & & $\begin{array}{l}\text { 伝統一存続型 } \\
\text { 伝統一転換型 } \\
\text { 現代型 }\end{array}$ & & & \\
\hline
\end{tabular}

以下の文献に基づき，筆者作成。

山崎 充『日本の地場産業』ダイヤモンド社, 1977.

清成忠男『地域の変革と中小企業』（上）日本経済評論社, 1975.

清成忠男「地場産業の現代的意義」『地域開発』192，1980，pp. 43-50.

板倉勝高『地場産業の発達』大明堂, 1981 .

青野壽彦「地場産業と地域振興」『地域開発』190，1980，pp. 1-6.

杉岡碩夫『中小企業と地域主義』日本評論社，1973.

北村嘉行「地場産業の地域的展開」（板倉勝高・北村嘉行『地場産業の地域』大明堂，1980）pp. 46-59.

合田昭二「伝統的漆器産業飛驒春慶の生産構造」『経済地理学年報』31-1, 1985, pp. 44-61.

インやファッションの面で先進的なユニークさ

を追究し，かつ製品差別化を強調することによ

って高加工度, 高付加価值製品を作り出してい る地場産咩」とした。一方，清成忠男は，大都 市型と地方都市・農村型に区分して，地方都市

・農村型は「一般に労働集約的な生産方法が採 用され，伝統的な技能を駆使する産地が少なく ない。生産性も必ずしも高いとは限らず，むし ろ低コスト・低生産型の産業が多い」と指摘し た。

立地による類型化を最も明確に行い, 各類型 別の存立形態を明らかにしたのは板倉勝高であ
ろう。彼は山崎充の「都市型」は, 「大都市型 で，地方都市の地方産業にはあてはまらない」 と指摘した。さらに技能指向・男子・親方一徒 弟制による技能伝承を柱とする「地方都市型」, 農家副業・女子・単純労働力を中心とするとい う特徽を持つ「農村型」を区別し,「大都市型」 「地方都市型」「農村型」という 3 つの区分を提 示した。

\section{B : 歴史による区分}

歴史による類型化は，大きく2つに区分でき る。すなわち，産地形成時期だけを基準とする 類型化と, 産地形成時期のみならず産地の歴史

57）前掲18）36頁。

58）前掲30） 3 頁。

59）前掲 4）49-52頁。 
的な展開をも加味した類型化である。

前者の立場から, 山崎充は, 明治時代を基準 として伝統型と現代型に区分した。これに対し て合田昭二は後者の立場から，製品・原料・製 造技術に伝統性を多く残している産地と大きく 転換した産地の相違が明確化している現実を考 慮するならば，伝統性の存続の有無・程度とい う側面も考慮した分類も必要であると主張し， $\lceil$ 伝統一存続型」,「伝統一転換型」,「現代型」 の区分を示した。このうち，「伝統一転換型」 と「現代型」が高度経済成長期以後に共通の方 向をたどり，それは大量生産で低廉化し，販路 拡大するもので，「量産化」の方向であると総 括できる。一方，「伝統一存続型」産地は，新 製品・量産品による市場の侵食, 生活様式の変 化に伴う需要減少，後継者不足などのために， 基本的には縮小・衰退の方向にある。こうした 分類を行ったのち，合田は，縮小・衰退傾向に ある「伝統一存続型」産地の中にも，生産量や 経営体数を, 維持あるいは増大させた産地が存 在する点に着目し，その代表的事例として飛驒 春慶産地を取り上げてその生産流通構造を分析 した。その結果，この産地は「伝統一存続型」 であるが，量産化の諸側面を多角的に提示しつ つ存立していると指摘した。

清成忠男は, (1)伝統的在来型, (2)在来化した 外来型，(3)変化した在来型，(4)新興型に区分し た。(1)は，明治期に日本の工業化がスタートし た時期に，既に一定の歴史を持って存在してい たタイプの地場産業である。これらの産地は, もちろん明治以降に変化を遂げた。けれども, こうした変化にもかかわらず，基本的には依然 として伝統的な技能に依拠しているものが，こ のタイプである。また，(3)は，もともとは(1)の
タイプでありながら，製品や生産技術を徐々に 転換し，もはや在来工業とはみなすことのでき ないタイプである。さらに，(4)は，昭和30年代 以降，新たに発生し産地を形成したタイプの地 場産業である。(1)や(2)は，一般に天然資源と労 働力に依拠して立地し, 従って特定の地域との 結びつきが比較的強いという特徵を有するが, (3)や(4)は，特定の地域との結びつきはかなり希 薄であると，清成は指摘している。

\section{$\mathrm{C}:$ 産業組織による分類}

次に，産地の産業組織による類型化を検討し てみよう。まず，山崎充は，「地域的分業」か ら「産地完結型」と「非産地完結型」に区分し た。この場合，特に企業経営の核心と目されて いるマーケティングにかかわる機能が産地内に 存在するかどうかが焦点となっている。また， 生産形態から「社会的分業型」と「工場一貫生 産型」に区分し，さらに「社会的分業型」の社 会的分業体制を，それを組織し統括する，いわ ゆるオーガナイザーが商業資本である場合と工

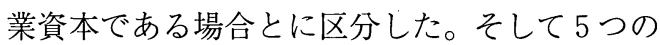
産地を事例として，社会的分業体制の実態分析 を行い，その特徵を明らかにした。

次に, こうした社会的分業関係から杉岡碩夫 と青野壽彦は垂直構造型と水平構造型という区 分を提示している。特に青野壽彦は, 各類型の あり方と地域経済との関連性に注目し，将来の 方向性を提示した。すなわち水平構造型の場合 には，それぞれの分業を担う企業は，複数の企 業から多様な発注を受けるので，自ずと生産・ 経営の技術・知識が蓄積され, 企業としての独 自性が大きい。このような地域では，そうした 蓄積の上に，さらに新しい展開をする可能性を もった企業が数多く存在し, 従って地域経済も

60）前掲 7 ）44-61頁。

61）前掲30） 3 頁。

62）前揭18）41-107頁。

63）前掲16）1頁。

64）前掲22） $5-6$ 頁。 
比較的安定したものとなり得るのである。これ に対して, 垂直構造型の場合は, 頂点に立つ企 業層の意向に地域経済の動向が大きく左右され ることが多い。また，多くの企業は，自ら新し い展開を試みる力を企業内に蓄積することが困 難な状態におかれている。従って, 地域経済に とっては, 地場産業の構造が, より水平的にな るような方向での分業関係の再編成が望ましい と指摘した。

一方, 清成忠男は, 「独立型」と「従属型」 の区分を提示し，さらに「従属型」を「商業資 本支配型」と「産業資本支配型」に細分した。 しかも，こうした類型区分にとどまらず，生産 形態によって「手工業」,「家内工業」,「マニュ ファクチャー」,「工場制工業」の 4 つの区分を も行い,これらの 2 種の区分を組み合わせて, 地場産業の存立形態を提示した。すなわち, 歴 史的にみれば，地場産業においてかつては「商 業資本に支配された家内工業型」が中心であっ たが，最近では「商業資本に支配された工場制 工業型」や「産業資本に支配された工場制工業 型」,「独立手工業型」,「商業資本に支配された 手工業型」なども充分に存立理由を有している。 すなわち, 地場産業の具体的な存立形態は産業 や産地の性格によって多様であって, 安直な近 代化によって消滅させてしまうべきではない。 従って，単純な進化論でわりきるべきではない と指摘した。

$\mathrm{D}:$ 市場による分類

最後に，市場による類型化について簡単に触 れておく。既に述べたように，地場産業は立地 する地域の需要を基盤に成り立つ「近在必要工
羓」と6は異なり，市場を全国あるいは海外に求 めている点から, 山崎充は「輸出型」と「内需 型」に区分した。彼はほとんどの産地がその市 場を輸出と内需の両方に求めていることから, 輸出と内需のどちらに相対的に高く依存してい るかを基準に区分することを提唱したのである。 しかし実際の分析では, 『中小企業白書』にお いて定義されている輸出比率10\%を基準に用い た。この分類では, 輸出型の代表的な業種とし, 繊維, 雑貨, 金属製品が挙げられ, 地方都市に 立地しているものが多くなっている。

以上, 地場産業の存立形態を類型化を通じて 検討してみた。しかし，地場産業概念自体が産 地の属性を背景としたものであり，存立形態は 多様であるため, 以上のような諸類型は理念的 であり，現実にはさまざまな中間形態が存在し， また産地が発達する過程で類型間の移動も生じ ている。従って, 地場産業の存立形態をより明 らかにするためには，発展段階に焦点を当てた 発展系列的な検討が必要である。

発展系列的な視点で存立形態を検討しょうと する傾向は，前述した清成忠男の産業組織と生 産形態を組み合わせた分析でみられたものの, 生産流通構造の変化を中心とした発展系列を提 示することによって, 地場産業の新しい理解像 を示したのは板倉勝高の研究であった。板倉は, 数多くの事例研究に基づいて, 生産流通体系を 中心とした類型化を行った。すなわち，大都市 型については，東京を中心に「卸問屋型」，「製 造卸型」「町工場型」に, 地方型については, 「小商品型」，「製造卸型」，「小工場型」に類型 化した。またこれらは単なる類型にとどまらず,

65）前掲50）45一-46頁。

66）清成忠男はこうした地元の需要を対象とするものを「地域産業」と名付けた。「地域産業」の範疇には，工業だけでは なく商業，サービス業も含まれている。

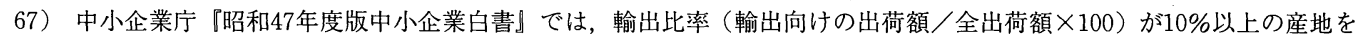
輸出型産地とした。

68）前揭30） 3 頁。

69）板倉 ·井出·竹内『東京の地場産業』, 大明堂, 1970 と板倉勝高編『地場産業の町』(上・下・ 3 ), 古今書院, 1978 · 1985。 
量産化の進展によって最前者から最後者へと変 化する発展系列をなすと考えられることを指摘 した。すなわち, 現存する各産地の生産流通体 系を相互に比較検討し，成長を前提とした発展 系列的な視点で, 鹵納的にこのような発展段階 を導き出し, 各段階の特性と, 発展段階の移行 において最も重要な役割を果たすのが商業資本 であることを明らかにしたのである。

以上，地場産業の存立形態と発展系列に関す る研究を検討した。存立形態に関する研究は, 一定の基準に基づいて類型化し，その類型に基 づく当該産地の位置づけや特性を明らかにしよ うとしてはいるが, 理念的な研究が中心となっ ている。一方, 発展系列的な視点からの研究は きわめて少なく，これまでのところ仮説にとど まっていると言えよう。両者の研究とも, 多く の産地は単一の類型に収まるものではなく, 種 々の類型が混在する場合が多いことを認めてい るにもかかわらず，類型化の妥当性を個別産地 の事例分析によって具体的に実証しているとは 言い難い。それゆえ，地場産業の存立形態を明 らかにするためには, 発展系列的な視点を念頭 におきながら，類型化に基づく事例研究を積み 重ねることが必要であると考えられる。

\section{IV 地場産業と地域社会}

（1）地域社会との関わり 地場産業研究に共通 して言えることは，地場産業を地域との関連 (「地場性」)において捉えていることである。 野和彦は（こう こうた「地場性」のとらえ方を 「産業論」と「地域論」に区分した。すなわち， 前者は「産業にとっての地域の意味あい」を把
握しようとする立場であり，後者は「地域にと っての産業の意味あい」を捉えようとする立場 である。

「産業論」的立場は, 従来の中小企業研究や 地理学研究がめざしてきた方向であり，「産業」 としての特性把握に偏る傾向があるため, その 産業がある地域に立地ないし集積している意味, あるいはその地域経済との関わりを深く究明す ることはほとんどなかった。「地域を研究対象 にしながら地域を利用するだけで，産業の研究 に終始する」という小口悦子の指摘はまさにこ うした状況を適確に示している。こうした「産 業論」的アプローチに対する批判に応え, 今後 の地場産業論の重要な課題として提示されたの が，地域経済あるいは地域社会のあり方に地場 産業がどのような意味をもっているかに焦点を あてた「地域論」的アプローチである。地理学 においてもこうした流れに沿い, 地場産業は社 会的分業体制をもつ地域集団であることから， 地場産業の担い手が集落を構成する一員でもあ り，それを集落の社会構造のなかに位置づけよ うとする「産業地域社会」論が大都市市内の地 場産業分析に関して提唱された。

「産業地域社会」とは, 生産・流通の交錯・ 結合関係だけでなく, 経営者・従業員とその家 族やその他の住民をも含めた詳細な分析によっ て明らかにされる, 産業を紐帯として生活が営 まれている住工一体の地域社会と定義される。 この分析視角は, 大都市以外の地場産業の研究 にも取り入れられてきた。松井久美枝は, 大都 市地場産業の「産業地域社会」面からの研究に 対して,「産業地域社会」が大都市の零細工業

\footnotetext{
70）前掲 4) 53-84頁。

71）中藤康俊「農村経済にしめる地場産業の役割」, 地域 $5 ， 1980 ， 32$ 頁。

72）上野和彦「伊勢崎機業と地域」, 地域 5，1980，19-24頁。

73）前掲22） 3 頁。

74）小口悦子「社会構造と地場産業」（前掲15)）191頁。

75）前掲22） 3 頁。

76）前揭14）参照。

77）松井久美枝「産地の構造と産業地域社会」，奈良女子大学地理学研究報告（II )，1986，114頁。

78）松井久美枝「製品転換と産地の形成過程」，人文地理36-6，1984，1-20頁と前掲77）114一-135頁。
} 
を支えてきた側面を明らかにし都市計画に対し て住工混在地区の重要性を説いた功績などを認 めた。けれども，産業を紐帯とした地域社会と 工業の両面からの動態的な視点からの解明が欠 けていたとし, 奈良県中和地域の靴下産地と吉 野地域の割箸産地を事例に，地域と地場産業と の関わりの視点からその発展過程を明らかにし た。小口悦子は下松町の眼鏡レンズ産業を事例 として，地場産業の担い手が村落におけるどの 階層から生じたかを, 村落内の血縁集団との関 係に着目して, 地域の社会構造と地場産業との 関係を検討した。さらに上野和彦は，「産業論」 あるいは「地域論」のどちらの立場をとるにし ても，具体的な地域との関わりを示す指標が実 証分析では重要であると指摘した。そして取り 上げた $6 つ の$ 指標の中で, 地域と地場産業との 関係を直接にあらわすものとして労働力を指標 とする分析を試みて，今後の研究の方向を示唆 した。

一方，「地域論」的アプローチの立場は，特 に，高度経済成長期に国民経済に従属するよう になった地域経済を自立化させるための手段と しての地場産業の役割を評価する, いわゆる地 域主義論者によって強調されてきた。すなわち， 地場産業が中央によらない産業であることに着 目し，地場産業と地域との関わりの中で，地域 社会に果たす地場産業の役割に関心が集まった。 こうした研究の中で, 石井広志らは, 宮崎県都 城市と和歌山県高野口町の地場産業を事例とし て, 地域経済への波及の推計を行い, 地場産業 が地域にどれだけの生産波及をもたらしている
か，及び，地域にどれだけ製品が販売されてい るかを明らかにした。それとともに，地域との 関わりを，(1)原材料仕入・製品販売特性，(2)関 連産業（設備・サービスの購入）特性，(3)雇用特 性の面から考察して，その波及効果の概念図を 示した。青野壽彦は，このような地場産業に焦 点を置く, 地域の経済・社会の構造分析を高く 評価し, 広い視野での地場産業と地域との結び つきを詳細に示すことが，地域振興を取り上げ る際には不可欠であると指摘した。さらに，地 場産業が地域経済に対して果たす役割を以下の. 3 点に整理した。

第 1 に，地域内での雇用や就業の機会の創出 がある。雇用の量的な側面からみると, 当該地 場産業に限らず，関連産業や企業，公共機関・ 団体によるものもこれに含まれる。関連産業は 製造業のみでなく, 原材料を供給する農林水産 業や鉱業，あるいは商業・サービス業にもひろ がる。また，雇用の質的な側面に関しても，地 場産業は地域内の多様な質の労働力を吸収する。 誘致企業の場合, 性別・年齢・就業形態の面で きわめて限定されるのに対し, 地場産業は産地 内社会的分業体制に基づいて, 工場常雇労働者 あるいは関連部門の自営業者としての就業とい ったように，地域内の労働力の質やその就業可 能な形態にあわせた就業機会を創出することも 可能である。

第 2 に挙げられるのは，地域内における経済 的蓄積の側面である。進出工場の場合は，付加 価值が地域外へ「漏出」する程度が大きい。対 照的に地場産業の場合，生産費に充てられた資

\footnotetext{
79）前掲74）191一200頁。

80）前掲72）19-24頁。

81）6つの指標としては，(1)労働力，(2)原材料調達，(3)製品販売（市場)，(4)関連産業，(5)金融，(6)地方自治体行政等であ る。

82）こうした研究の例としては,

(1)山崎充の前掲18）108一330頁と前掲19） 1 -42頁。

(2)石井広志・北村維梓・立川淳一・樋口美敬「地域活動の中核としての地場産業 1，2，3 」, 地域開発190, 1980, 26 -76頁。

(3)清成忠男の前掲50)43一-50頁などを挙げられる。

83）前掲22） $3-5$ 頁。
} 
金や, 生み出された付加価值の地域内での循環 が比較的大きいため, 地域内の経済活動を活発 化し，地域内における経済的蓄積を増大させる ことも可能となる。

最後に, 地場産業の場合, 企業の中枢部にあ たる人材や技術等が地域内にあり，しかも地域 内に蓄積されるため，こうした蓄積が業種や生 産品種を転換しながら存続することを可能にす る重要な要因の一つとなる。

一方, 山崎充は, 以上の地域経済に及ぼす役 割以外に, 公共的・福祉的・文化的貢献と, 魅 力ある地方都市づくりへの貢献, 魅力ある仕事 の提供など，地域社会・文化面に果たす地場産 業の役割を指摘した。

以上のように，地場産業の存在ないし発展は 地域経済のみならず，地域の社会・文化・教育 ・福祉等に対しても幅広い波及効果を及ぼして いることが指摘され，地場産業の利点が強調さ れている。しかし，「地域論」的アプローチは 現在のところ, 理念が先行し, 実証分析が遅れ ているという指摘もある。従って, 今後は, 地 場産業と地域社会とのかかわりについての実証 分析の指標を含めた分析方法を確立し，それに 基づいた体系的調査を実施することが課題とな る。地場産業と地域との結びつきの実態が具体 的に明らかにされるならば，地場産業の性格規 定や地域振興における地場産業の位置づけがよ り具体化されるに違いない。

（2）地域開発における地場産業の意義 戦後 日本の地域開発政策の中核を形成しているのは 工業立地政策であり，1962年の全国総合開発計
画以後の各次総合開発計画の成否の多くは，関 連する工業立地政策の成否に大きく左右されて きたといえるであろう。なぜなら，全国総合開 発計画は過疎・過密の解消, 地域格差の是正等 を目的としており，そのためには雇用と所得の 全国土的平準化，すなわち，工業の全国土にお ける発展によって最も効率的に達成されるであ ろうという見解が，政策担当者に限らず，広く 国民の間に共有されていたからである。実際， 高度経済成長期，特に1970年代前半期には，工 場分散と財政による所得再配分などによって， 地域格差は縮小した。しかし，1979年の石油危 機以降の低経済成長期に入ると，高度経済成長 期のように地方への工場分散に大きな期待を寄 せることはできなくなり，また，財政を通じた 地方への所得移転効果にも期待をかけることが できなくなった。その結果，地域振興が必要な 地方においては，地域経済それ自体の振興が追 求されるようになり，自立的な産業化を進めざ るをえなくなった。そんの結果，地域経済の振興 が多くの議論を呼ぶようになった。

そして,「高度成長期の国主導の重化学工業 化政策に対するアンチ・テーゼ」として唱えら れた地域主義を背景にして，経済の地域化を図 るための内発的な地域開発論が提示された。内 発的な地域開発とは，「地域が，地域に存在す る資源，労働力，伝統的技術，等々，要するに 地域に内在するポテンシャルを最大限に活用し て主体的に工業化をおし進めるという形態の地 域開発」と定義されている。清成忠男は，こう した内発的地域開発を進めるにあたっての基本

\footnotetext{
84）前掲18）313-330頁。

85）前掲72）19頁。

86）伊藤喜栄「工業立地政策の展開と工業立地動向」(川島哲郎・鴨澤踇編『現代世界の地域政策』大明堂, 1988), 243頁。

87）清成忠男『地域産業政策』, 東京大学出版会, 1986, 15頁。

88）前揭50） 43 頁。

89）前掲17）277頁。

90）経済の地域化は, 経済の地域内循環, すなわち, 地域の資源を加工し, 製品にし, 地域内で流通させ, 消費させるとい うことを意味する（清成忠男・武井秀夫編『地域経済の構想』，学陽書房，1981，517頁）。

91）清成忠男「内発的地域開発を考える-2」, 地域開発 $167,1978,1$ 頁。

92）前掲91).
} 
的な考え方を次のように提示した。すなわち， (1)経済の地域内循環を可能な限り拡大させる。 (2)バランスのとれた地域的産業構造を指向する。 (3)諸産業の有機的結合, とくに農業と工業のつ ながりに配慮する。(4)産業と生活の地域内リサ イクルに配慮する。(5)地域の風土的特性，地域 の資源，地域の労働力を最大限に活用するなど である。そして, 以上の内発的地域開発を推進 するためには, 既存の産業の体質的転換, すな わち，産業に地域をなじませるのではなく，地 域に産業をなじませるような産業の手直しの必 要を指摘した。特に，製造業においては，環境 を破壊するまで規模の利益を追求する時代は終 わったとして，地域経済の自立化を図るための 新たな産業の担い手として，中小企業を確立す る必要があると強調した。

中小企業は，大企業に比べて全国にくまなく 分布しており，地域との結びつきが極めて強い。 すなわち, 中小企業と地域は, 密接不可分な相 互依存・補完の関係にあり，低成長期になって 中小企業の果たすべき役割と責任は一段と高ま った。それは，中小企業の利益は地域の利益と 一致し，地域住民の福祉へとつながるからであ る。

以上検討したように，いわゆる「地方の時 代」に入り，地域経済の独自の意義を認めたう えで，中小企業問題が把握されるようになった と考えられる。こうした中で，特に注目を浴び ているのが地場産業である。それは，地場産業 か，自然的 - 歴史的 - 社会的 - 文化的 · 精神的 風土と調和を保ちながら地域社会に定着してい るからである。言い換えれば，地場産業はもと
もと地域の資源を活用し，地域の風土の中で育 まれてきた産業である。資源が枯渴した場合で あっても地域に蓄積された独自のノウハウに依 存して存立し続けている場合が多い。地場産業 は地域を形成する産業であり，地域の人々の生 産を支える産業として展開してきた。同時に， 地域の第一次産業とも直接あるいは間接に関わ りをもち，まさに地域になじむ産業である。

野原敏雄は, 地場産業の現在の役割の大きさ は,「産業近代化論」的な個別企業の努力のみ でつくられてきたわけではないと指摘し，地域 へのなじみを強調した。すなわち，地場産業は， 「近代化論」による一部上層の経営拡大とその 他の多数の切捨て論議や，現実に進行した全般 的な下請化の危機に対して，地域の資源，労働 の技術的な蓄積や長期間にわたって整備されて きた産業基盤に依拠し，協同組合のような組織 を通じた共同の力でもって，産地が全体として 対応することによって存続してきたとしている。

以上の結果をまとめると，地域経済を支える のに，地場産業だけに依存することができない のは言うまでもないが，地場産業は地域になじ む産業であり，しかも，地域のベーシック産業 であることから，地方経済を活性化に導くこと ができるのはこれしかたいという指摘もあり， 「地方の時代」の地域開発における地場産業の 意義は明らかに大きいと考えられる。こうした 中で，現在の地場産業を少しでも拡大し，さら に地域の特性を生かした新たな地場産業を生み, 育てていくことは，今後の地域開発の中での新 しい課題たなっていることを十分認識すべき時 になっているという, 今野修平の指摘を引用し

93）百瀬恵夫・北谷一松編『地域産業とコミュニティ』，白桃書房，1986，3-4 頁。

94）前掲93） 7 頁。

95）清成忠男は，産業のタイプと地域とのかかわりの側面で，地域の利用者としての産業と，地域の形成者としての産業に 区分した（清成忠男・森戸哲『地域社会と地場産業』，日本経済評論社，1980，4 頁)。

96）前掲50）48頁。

97）野原敏雄「地域経済の変貌と中小企業」(渡辺睦・前川恭一『現代中小企業研究 (上巻)』, 大月書房，1984）225一226 頁。

98）板倉勝高『日本工業の地域システム』, 大明堂, 1988，150頁。

99）今野修平「地域開発における地場産業」地域 $5,1980,43-49$ 頁。 
て本節のしめくくりとする。

( 3 )地場産業の問題点と将来ヴィジョン 高 度経済成長から低成長経済への転換を契機に, 地場産業は「危機」と「期待」という相反する 二つの面から関心を集めることになった。すな わち, 高度経済成長過程における存立基盤の変 化と, その後の円高と発展途上国の追い上げ, 等々との関わりで地場産業の問題点がクローズ アップされる一方, 地域振興の立場からも地場 産業に大きな期待が寄せられるようになった。 そこで, 地場産業研究をいっそう進展させる契 機となったとも言える地場産業の問題点を検討 し, 将来のヴィジョンを模索してみよう。

地場産業の問題点は, 基本的に各経営体の経 営上の問題点の総和であるが，地場産業自体が, 経営的特性が異なる多数の業種, それを構成す る膨大な数にのぼる企業の集合体であるが故に, 問題点の摘出も個別経営体よりは各産地を単位 とした分析によって行われている。さらに, こ れらの研究は, 産業論的分析に依拠するものを 除けば，産地振興を目的に個々の産地を研究対 象にしながらも, 高度経済成長期以降の地場産 業をとりまく環境変化と, それに対応する過程 で生じた矛盾をとらえようとしたものが多い。 たとえば山崎充は，高度経済成長期には，(1)生 活様式の洋風化による消費構造の変化, (2)労働 力不足, 資源 - 原材料不足, 立地環境の悪化な ど, 供給の制約条件の顕在化, (3)地場産業に対 する経済的・社会的評価の変化による後継者難, などの問題点が地場産業に表面化し，これらの 問題に対処するため, 量産体制の確立を目指し てきたと指摘した。また，低成長経済の定着以 後は, 需要変化と国際環境の変化の結果, 量産 体制の限界と矛盾が表面化して, それ自体が最
も主要な問題点となったことを強調した。清成 忠男は, 1960年代後半以後の労働力不足の深刻 化と発展途上国の追い上げへの対策としてとら れた資本集約的生産体制への移行の結果，低成 長期になって露呈した矛盾を強調し, 資本集約 化がもたらした結果を次のように整理した。す なわち，(1)資本集約化が進んだ結果，技能に依 拠していた産地としての独自性が失われ，他産 地との競争が強まった。(2)生産第一主義的資本 集約化であったため, マーケティング能力や技 術力, さらには製品開発力がこれに伴わない例 が少なくなかった。(3)所得水準の上昇に伴い増 大した高級品の需要に応じるために伝統的技能 に依拠して生産しょうとしても，すでに技能は 失われ，それも困難になった。(4)資本集約化の 結果, かえって発展途上国の参入が容易になっ てきた。

そして, 量産型大衆品への需要に応じること も必要であることから資本集約化がすべて悪い わけではないとしながらも，伝統的な技能をも とに開発した高級品と普及品とのバランスをと ることの重要性を指摘し，伝統的な技能にいか にして近代的技術を取り入れるかといった点に 配慮しない安易な集約化は, 決して地場産業の 近代化を意味しないし, むしろ地場産業解体の 要因にすらなっていると喝破した。

これに対して地理学では地場産業をとりまく 環境変化を含めた問題点を正面から取り上げよ うとするよりは，むしろ問題点に対応する過程 で生じた生産流通構造を中心とした産地構造の 変化に研究の力点が置かれた。その中で坂野優 は, 愛知・岐阜・三重 3 県の伝統産業を調査し, 11 の問題点を指摘した。これに対して板倉勝高 は,これらのいずれもが地場産業一般の問題点

100）下平尾勲『現代伝統産業の研究』, 新評論, 1978や各産地別の「産地診断報告書」など。

101）前掲18）149-272頁。

102）前掲30） $7-8$ 頁。

103）坂野 優『東海三県の伝統産業』, 中部日本教育文化会, 1978.

104）前掲 4) 144-177頁。 
であると指摘し，次のように整理して考察した。 すなわちまず，(1)機械・設備の貧弱，規模の零 細性は，問題点と言うよりもむしろ地場産業に 固有の特性であり，これらの特性を持つがゆえ に, 新規参入や関連部門への転向が容易なので ある。(2)従業員の高齢化，技術習得に長時間を 要すること, 後継者難, 低収入などの問題点は 労働力に関わるものである。技術習得に時間が かかる割に低収入であるために新規就業者に乏 しく, 後継者難となりやすく, 若年層の追加が なければ従業者の老齢化が進む。こうした悪循 環は，大都市型よりもむしろ，技術・技術指向 性のが強い地方都市型産地で顕著である。(3)代 替品・類似品の進出, 輸出の伸びなやみ, 外国 産地の成長といった問題は商品にまつわる問題 である。しかしこうした問題点は，各産地が現 在の地位を維持しようとする保守的な姿勢から 生まれるものであり，自らの技術・技能の不足， 創造力, 開発力の貧困を露呈しているにすぎな い。すなわち, 特別な技術指導がなくても, 類 似品の製造が可能な傾向が地場産業には一般に みられる。けれども類似品の進出を食い止めて, 独占利益を得ようとするよりは，技術を公開し て後進産地を指導しつつ, 販売力を強化して, 開発力をつける方が，より積極的姿勢である。 従って，上記の問題点は，地場産業全体から考 えると，むしろ発展指向的な方向性を目指すよ いきっかけとなり得る。(4)作業環境の悪さと公 害問題は, 都市・集落の構造上の問題として捉 えることができる。しかし，作業面積当り従業 者の割合が非常に高い点などは現実問題として， 作業環境が良いとは言えないことを示している。 この点は, 地場産業が住一産混在の形態をとる 場合が多いことと深い関連がある。公害問題に 関しては，重化学工業よりも深刻であることを 意味するのではなく, 少々の騒音や振動・悪臭
・污水などはこれまで大きな社会問題とならな かったが，近年，生産空間と生活空間が分離が 志向され, 生活環境に対する社会の認識が変化 したために，表面化するようになったという意 味であると指摘した。

こうした地場産業の問題点は, 現在の地場産 業が経営において直面しているものであること は確かであるが，必ずしも地場産業に限られる ものではない。というのは，前述した地場産業 をとりまく環境変化は, 日本経済全般, 少なく とも先端産業を除く中小企業全般の問題点とな っている。そして，坂野優の研究で指摘された 個別産地における問題点も，地場産業に固有な 問題というより，零細中小企業全般に関わる問 題である。この点で板倉勝高の指摘は有益であ り，地場産業の問題点の考察は，個別経営体あ るいは個別産地よりはむしろ地場産業全体を見 渡して，地場産業固有の性格に基づく問題点の 解明を行うべきである。

こうした問題点にもかかわらず，地場産業は 地域経済振興の「主役」として期待されている ことが多いため, 次に, 望ましい将来ヴィジョ ンとその振興策を見いだそうとする研究を検討 する。この方面の研究は主に地域主義論者によ って行われてきた。

地域主義論者による研究は，低成長経済にお ける経済の地域化の当為性と, 需要環境の変化 に照らし合わせながら地場産業のヴィジョンと その振興策を提示している点で, 終始一貫して いる。

清成忠男と板倉勝高は，次のような認識に基 づいて地場産業のヴィジョンを提示した。すな わち，日本の国民所得は欧米先進国を上回って おり，しかも大量生産型の工業製品に対する需 要はほぼ一巡している。そして，いまや「生活 の質」が問われるようになり，消費需要の多様

105）清成忠男『地域主義の時代』, 東洋経済新報社，1979，93一-95頁。

106）前掲 4）17頁。 
化が進展するとともに，本物指向や高級品に対 する需要が強まっている。成熟した経済におい ては，多品種少量生産型の技術集約的な製品の 需要が拡大傾向にある。そして，こうした需要 に対応できるのは地場産業に他ならないとの指 摘である。山崎充は，地場産業の将来に対して， 手放しの楽観はできないにしても，さほど暗い ものではないと述べ，その理由として，前述し た成熟社会における需要環境の変化に加えて, 長い歴史の中で，危機が革新の起爆剤となって 苦難を克服してきた地場産業特有の歴史を挙げ ている。そして, 将来にわたって発展的存続の 可能性を持つ地場産業は,「非価格競争力」が 非常に強くなければならないと主張し, 強い 「非価格競争力」を持つための条件として $5 つ$ を指摘した。また，これら 5 つの条件を整える ための地場産業の再生方向を 3 つ挙げ，その方 向を具体化するための 4 つの「戦略」を提示し て，地場産業再生の方向性を示した。これに対 して清成忠男は，1950年代後半以降の地場産業 の推移をふまえて，「まちづくり」との関連で 望ましい地場産業像を提示した。それは，地域 特性を生かし，他地域の下請産地とならないよ う独立性を保ちつつも，モノカルチュア的には ならず，安易な資本集約化を避け，分業メリッ トを生かし加工度の高い製品を生産する産地, と整理できよう。そして，地場産業の育成はけ っして容易ではないし, 即効的な効果も期待で きない。しかし，地場産業の振興は「まちづく り」にとって重要な役割を果たすことを視野に 入れた革新が望ましいと指摘し, 政策的には, これまでのような画一的な近代化政策をとらな
いことがなによりもまず肝要であることを強調 した。

しかしながら，以上の諸研究においても，こ れまでのところ, 地場産業の振興の必要性を強 調するあまり，理念が先行し，実証分析が遅れ ていると言えよう。それは, 地場産業の問題点 と成熟社会における将来ヴィジョンをふまえ， 発展指向的な再編成が行われた産地と行われな かった産地との比較分析などを通じて，ヴィジ ョンと振興策の意義を吟味した研究がほとんど 見あたらないためである。それゆえ，これらの 課題をまず具体的な事例研究を通じて詳しく検 討し，総合・一般化することが，極めて多様・ 異質・多元的存在である地場産業の研究にとっ て重要であると考えられる。こうした作業を経 てはじめて，いままでの地場産業に関する対症 療法的な政策が改善されよう。

\section{Vおわりに}

本稿では地場産業研究の枠組みを再構成する とともに研究課題を明らかにすることを目的に, これまでの日本の地場産業研究を振り返ってき た。その際, 地理学だけでなく諸分野で行われ た研究結果を有機的に統合する形で把握しょう とした。得られた結果を簡単にまとめ，若干の 課題を提示し結論に代えたい。

従来，地場産業は，在来・伝統工業と同等視 されてきた。しかし，日本経済の高度成長期以 降に生じた産業構造の変化と, 低成長経済期以 降の課題を把握・解明するために「地場産業」 概念が成立し，さらに，地域主義を思想的背景 として, 地場産業に地域経済発展の担い手とし

\footnotetext{
107）前揭19）282-289頁。

108） 5 つの条件とは，(1)社会的分業体制が単純労働集約的でなく，技能労働集約的，知識労働集約的になっていること，(2) 製品企画力, デザイン開発力，メカニズム開発力を保持していること，(3)外部経済を形成している産地内異業種の関連産 業, 素材供給産業との高度な技術的結合をもっていること，(4)多品種少量生産を堅持していること，(5)消費者ニーズの迅 速な製品企画，生産へのフィードバックを必要とすることなのである（山崎充『日本の地場産業』, ダイヤモンド社, 1977, 282-292頁)。

109）前掲19）53-84頁。

110）前掲105）96-106頁と前掲30）8頁。
} 
ての役割が期待されるようになった結果，地場 産業研究は従来にも増して盛んに行われるよう になった。

地場産業研究の立場は, 地理学を中心とした 産業把握の新しい概念として地場産業を捉える ものと, 地域主義論者を中心とした地域政策手 段の一つとして地場産業を捉えるものに区分で きる。前者による研究は, 当該地域における地 場産業の構造とその变化の解明が中心であり, 一方, 後者の立場からの研究は, 現状の解明が 最終目的ではなく，そこから将来のヴィジョン や振興策を提示することに力点が置かれてきた。 地場産業の地位とその变動に関する研究では, 高度経済成長期以降を中心に，地場産業を取り 巻く環境変化とそれに基づく構造変化が主に扱 われてきた。これらの研究の着眼点は, 需要・ 供給構造や国際関係であった。しかし，3つの 側面間の相互関連が明らかにされていないこと もあって, 提示された結論は依然として仮説に とどまっている。これは, 環境変化が及ぼした 影響が地場産業とその他の産業とでどのように 異なるのかという点に関する実証的検討が皆無 に等しいことに原因があった。

地場産業の存立形態に関する研究は, 一定の 基準によって類型化して，その類型に基づいて 当該産地の位置づけや特性を明らかにしょうと したものや，理念的なものが中心となっている。 類型化の基準は, 主として, 立地, 歴史, そし て産業組織が用いられた。類型化は発展系列的 な側面から捉えることも可能であり，むしろそ の方が地場産業の方向性をも示せることから， 重要性を持つであろう。しかし，こうした研究 事例は極めて少ない。

地場産業と地域との関連性, すなわち, 「地 場性」の解明は, 地場産業研究の最も根本的な 課題である。なぜなら, 地場産業概念それ自体 が地場性を基にして定義されているからである。 さらに，地域経済・社会に対する地場産業の役
割への関心が高まるにつれ，「地域論」的アプ ローチが地場性の分析に新しい視点を与えた。 「地域論」的アプローチにおいても, 地理学で は「産業地域社会」の側面からの研究が主流を 占めているのに対し, 地域主義論者は地場産業 の地域社会における役割を評価し，「地方の時 代」の地域開発における地場産業の意義を強調 しょうとした。

地場産業の問題点, ヴィジョンとその振興策 に関する研究は, 地理学ではきわめて少なく, 主に経済学で進められてきた。これらの研究は, 地場産業を取り巻く環境変化と, それに対応す る過程に抒ける矛盾を，問題点として捉えたも のが多い。こうした問題点は, 地場産業に限ら れた問題点とは言えない。従って, 地場産業固 有の性格に基づいた問題点の解明が今後の課題 となっている。こうした課題に取り組むことに よって, 低成長期における経済の地域化の当為 性と需要環境変化との関連を基に提示されたヴ イジョンとその振興策が,より現実に即したも のとなると考える。

以上述べたように，日本における地場産業の 研究は「地場産業論」として定着する段階まで 深化してきた。しかし，諸学問分野間に共通し た枠組みや課題を前提として研究がなされてき たわけではない。地場産業研究には大きく $2 つ$ の流れがあり, 地理学者による研究と地域主義 論に依拠する経済学者の研究には明瞭に違いが みられるのである。

地理学では, 主に地場産業を新しい産業把握 の概念として捉える立場から，個別産地の事例 研究を通じた存立基盤を解明することに貢献し た。しかし, 地理学での枠組みでは現在の地場 産業の諸問題を捉えるのには不十分であり, 特 にヴィジョンと振興策を包含した視点が必要で あると考える。一方, 地域主義論者の研究は地 場産業の性格を解明しようとしたが，その焦点 は，主に地域社会に扔ける地場産業の役割を明 
らかにすることであり，地場産業が低成長経済 期に地域経済振興の「主役」として期待される 理由の検討とその振興策の提示に置かれた。従
って地場産業の発展の当為性を前提にする傾向 が強かったため，理念が先行し，実証分析が遅 れてきたと言えよう。 （名古屋大・院）

\section{Significance and Issues in the Study of Indigenous Industry}

\section{Chul-Woo LEE}

A large number of studies and researches on "Indigenous Industry" have already been done in Japan, using different approaches to various subject issues. At this point in time when almost two decades have past since the end of the postwar rapid economic growth period, it has become possible for us to objectively evaluate the content of structural change which took place in an indigenous industry during that period.

This paper aims at the review of academic achievements made so far in this area of concern so as to identify still remaining issues and problems and to suggest an alternative framework of study to respond to the above-identified issues and problems.

"Indigenous Industry" was generally seen as synonymous with traditional industry. In the 1970's, however, the concept of an indigenous industry was newly introduced to understand the changes in its structures during the postwar rapid economic growth period and the accompanying issues and problems in the period of low economic growth after the 60's. With the emergence of "Regionalism", the study of indigenous industry gained further momentum when its dynamic role was emphasized as a main factor in regional economic development or growth.

In the studies of position and its change in indigenous industry, the main focus was given to the aspects of environmental changes and their resultant effects on structural changes of indigenous industries, particularly in the post high-growth period. The three dimensions of analysis adopted in these studies were the demand-and-supply structures of the products of indigenous industries concerned, and the international relationships in the said context. These studies, however, seem unsuccessful in that the conclusions given still remain in the range of hypothesis mainly because of the correlation among the said three dimensions being left obscure.

In the studies of the development base of indigenous industry, it was attested that among the most salient factors in the development base are production and marketing structures based on social division. Those structures, however, are very much diversified. Hence, they must be categorized in accordance with such criteria as location, history, and industrial system so as to give account to positions and characteristics of respective industries within this framework. In my view, categorization based on the pattern of development process of indigenous industries would bear more meaningful significance, for it would help us better recognize the direction of industrial development. The studies conducted in this suggested line have been very few so far.

One of the most fundamental and challenging works for us is to specifically clarify the interrelationship and/or relevance between indigenous industries and local character- 
istics of the industry's area. The "Regional Approach" has arisen, along with the growth of interest in dynamic role of indigenous industries in regional economy and society, and the studies in this line have been more actively pursued. The issues focused on in this approach, however, have differed from one another according to academic stance. For example, Geographers utilized this approach mainly for the study of industrial communities, while, Regionalists more positively estimated and emphasized the important role of indigenous industries in regional development.

Studies on the problems, visions, and promotion policies of Indigenous Industries have so far been done more in the field of Economics rather than in Geography. Most of those studies commonly regarded as problems the issues of changes in environmental factors in which indigenous industries operated, responses to those changes from the industries, and resultant contradictions in the interaction process. Hence, those issues must further be examined based on the unique, specific characteristics of indigenous industries. Future vision and promotion policies can become more realistic and effective only when we take this sort of approach to issues of indigenous industries.

As described above, the studies of indigenous industries in Japan seem to have reached the point where "theory of indigenous industries" has established itself as one of the major academic foot-holds. However, those studies have by no means been done based on the framework of study and issues commonly shared among different academic disciplines.

There are two major trends in studies of indigenous industries. Geography has contributed much to the understanding of development base and conditions of indigenous industries through a number of case studies. But the study framework adopted therein is not enough to comprehensively grasp the current issues in indigenous industries. There is much to be desired particularly coucerning future vision and promotion policies. Regionalists have meanwhile adopted a somewhat normative approach in that they took empirical studies relatively lightly in the strong belief that indigenous industries should be strongly promoted because of their active role in regional development. Under this thrust, they naturally put their efforts in to studies of characteristics of indigenous industries as well as in presenting appropriate promotion policies.

Key Words : Indigenous Industry (Ziba Sangyou)

Industrial Community (Sangyou Tiiki Shakai)

Regionalism (Tiiki Syugi)

Regional Approach (Tiikiron-teki approach)

Social Devision (Syakai-teki Bungyou) 